\title{
The Impact of Paradise in Persian Garden Design Nafisi $\mathbf{N}^{*}$, Abbas MY and Nafisi S \\ Faculty of Architecture, Universiti Teknologi MARA (UiTM), Malaysia
}

\begin{abstract}
From the time that Islam came to Iran, Iranian through Islamic centuries until now a garden is a kind of paradise in people opinion. Surely the reason that caused such belief is dryness of Iran plateau. In the ancient pieces found in Iran, one can see the validity of the gardens, in form of initial stage of time from the mountains and long periods big Iranian plateau, they cultivate their forms, sketch different aspect of their life and their opinion on the earthenware. On some of these pieces, trees surround the river, and some others show the river in four parts. This kind of crossing designation that has an axis longer than another one, this form of design called Chahar Bagh. This type of design is common in Sassanid period (642-224). Respect to water and even worshiping flowing water and river basin, is common in this period. In Sassanid period rulers' selected particular place to sketch their religious view and descriptions about their victory in huge stones, in each place a river basin that was overflowed by spring is created at the foot of stone. A little more than a millennium, one of Qajar king in 19th century 13th Hijra selected such place in south of Tehran called ray and ordered to create a portray of him carved in stone while he sat on his throne. Because the water is a fundamental factor for the creation a garden, so its source has a vital importance.
\end{abstract}

Keywords: Persian garden; Paradise; Garden design; Islamic centuries; Chahar Bagh

\section{Introduction}

\section{Function of persian garden}

One of the main purposes of the existence and building of these gardens was to provide various forms of relaxation such as leisurely or even spiritual. "Pairi Daeza" is a Persian phrase meaning enclosed space [1]. This term can also be seen in Christian mythology who had adopted it to define and describe paradise on earth, i.e., Garden of Eden. The gardens could be built with reliance on any Feature desired by the architect like nature or structure, but irrespective of these aspects, its basic goal must be to encourage sentimentality and thoughts [2].

One of the functions of building Persian gardens was as a way of escaping from the harsher landscapes. Modern gardens such as the magical nightingale gardens of Tehran have followed this concept since 5th century B.C. The garden of Cyrus was built in a geometric manner with watercourses made of stone. In Islam, these four rivers were considered as the paradise of water, milk, honey and wine. These concepts spread quickly around the world and adaptations can be seen in the Moorish gardens of Spain to Mughal gardens in India [3].

Greek historians that Iranians used to have gardens around their private residences more than 3000 years ago. Iranians called these gardens paradise (heaven). Later people in various nations used such garden style, and the work paradise was used in many languages such as French, Greece, Semitics, and other languages. In his encyclopedia, Ali Akbar Dehkhoda says paradise is a word from median language and it means garden and orchard.

The word Paliz in Persian and Ferdos used in Avesta twice, Paradise, composed of two parts, one is Piri which means surrounding and other is daeza which means planting trees and flowers around the building. This word changes to Paliz in Pahlavi language and it's also used in Dari Persian language, although nowadays vegetables such as cucumber, watermelon and melon are called Paliz. In Achaemenian period and after that there were numerous gardens all over Iran, such that Gezenfon * pointed to them several times. This kind of garden did not exist in ancient Greece, but Greece people were interested in them and used them by the same word paradise [2].
Nowadays this word in the form of Paradisos in Greece language means garden and in French in the form of paradise means heaven. According to Geznefon* (four and half centuries, B.C., there was a beautiful and huge garden in Lidia called paradise. The famous Hanging Gardens of Babylon (which do not exist today) were built by Nebuchadnezzar for his Iranian wife, Amitis, and had a similar design portraying paradise. The gardens remained until Alexander the Great time.

Another Persian word for the garden is Bagh, which is derived from Pahlavi and Soghdi language. While some people indicate that Bagh is a common word in Persian and Arabic, some also consider it an Arabic word and plural of Beighan [4].

\section{Methodology}

The current study will use credible sources and study Persian garden through descriptive, the garden will be deliberate as an original and living symbol of culture.

\section{Build garden in Islam period}

In the companion with following Islam by Iranian, Persian garden prevalence to other Islamic regions. Believe in paradise, which is the world after this world, is common in religions. In their view, human die and their spirit go to another world, in which happiness and harmony exist, and their lives become as they have dreamed of. However, various religions have different beliefs of this view. In Quran, Muslims religious book, Jannat (heaven) is described as what we see in nature, with shades, trees, flowers, and streams, therefore Muslim architects tried to portray Jannat through their designs by using the same elements [5]. Holy Quran describe paradise in following way: there are gardens

*Corresponding author: Nazanin Nafisi, Faculty of Architecture, Planning \& Surveying, Universiti Teknologi MARA (UiTM), 40450 Shah Alam, Selangor, Malaysia, Tel: +60355442000; E-mail: n.nazanin67@gmail.com

Received February 23, 2016; Accepted May 31, 2016; Published June 10, 2016

Citation: Nafisi N, Abbas MY, Nafisi S (2016) The Impact of Paradise in Persian Garden Design. J Steel Struct Constr 2: 113. doi:10.4172/2472-0437.1000113

Copyright: ( 2016 Nafisi N, et al. This is an open-access article distributed under the terms of the Creative Commons Attribution License, which permits unrestricted use, distribution, and reproduction in any medium, provided the original author and source are credited. 
beneath their castle rivers flow and every time a fruit given to them, there is a question here that.

So in other words, Persian architectural designs try to portray Jannat by displaying the characteristics of heaven, that is in confirm with characteristics of it, about remember the image of future paradise and they try that all beauties and benefit of fruit in several area and in all seasons of the year provided a close ecosystem and free from environment, and this image of heaven considers trees, fruits, everlasting trees, and their beauties and benefits.

\section{Ferdous and rozat-al-jannat}

"People who believe and do worthy thing, their stage is paradise garden" (jannat-al-ferdous). It is said that prophet Mohammad has said when you ask from God, ask from Jannat and the high point in it. Above it there is the empyrean OD divine (arsh-o-rahman) and paradise spring gushes from there. Rozat-al-jannat is one name of paradise that existed in Quran [5]. According to majma-ol-bayan, the word Rozeh represent the green land and plants and the word Jannat portrays the gardens that are placed in the center of the lush and green land.

\section{Persian garden and paradise}

From the time that Islam came to Iran, Iranian through Islamic centuries until now a garden is a kind of paradise in people opinion. Surely the reason that caused such belief is dryness of Iran plateau. In the ancient pieces found in Iran, one can see the validity of the gardens, in form of initial stage of time from the mountains and long periods big Iranian plateau, they cultivate their forms, sketch different aspect of their life and their opinion on the earthenware. On some of these pieces, trees surround the river, and some others show the river in four parts [6]. This kind of crossing designation that has an axis longer than another one, this form of design called Chahar Bagh. This type of design is common in Sassanid period (642-224). Respect to water and even worshiping flowing water and river basin, is common in this period. In Sassanid period rulers' selected particular place to sketch their religious view and descriptions about their victory in huge stones, in each place a river basin that was overflowed by spring is created at the foot of stone. A little more than a millennium, one of Qajar king in 19th century 13th Hijra selected such place in south of Tehran called ray and ordered to create a portray of him carved in stone while he sat on his throne. Because the water is a fundamental factor for the creation a garden, so its source has a vital importance [7]. Plateau parts of Iran have less than $30 \mathrm{~cm}$ rain annually. Some of the parts in Iran have the same climate as New Mexico and Arizona, with little rain, and dry weather, while the northern parts next to the Caspian Sea is more temperate. In the dry parts, the most important source of water is the snow from the next mountains, and what remains of them in the winter. In the spring, the snow melts and creates small streams, and brooks, which are mostly absorbed by the hot stones and gravels of the desert in the plateau parts. In few month of the year that water flowed in these brooks, people establish some channel for irrigation garden and farms. Necessary water can be provided from spring and well, but the main instrument for providing water in Iran is drain [8].

\section{Garden in the islamic world}

The Qur'an makes numerous references to gardens and portrays it as an analogy of life in paradise.

Allah has promised to the believing men and the believing women gardens, beneath which rivers flow, to abide in them, and goodly dwellings in gardens of perpetual abode; and best of all is Allah's goodly pleasure; that is the grand achievement (Qu'ran9.72).
There is a wide range of surviving Islamic gardens around the world, Spain and Morocco in the west, to India in the east. For example, a few well known Islamic gardens include the Taj Mahal of India and the Genera life gardens in Spain [9]. One of the most common themes of the Islamic garden is the use of water and shade. This makes sense since Islam generally originated from and existed in hot and arid climatic nations. Islamic gardens usually include four main canals that carry water to the fountain in the middle and each of these canals is supposed to represent the four elements of life; milk, honey, wine, and water. A four-fold garden such as this is also known as a Chahar-Bagh [9]. In the Islam, paradise is known as a place full of fruit trees like pomegranates and dates, which provide a nice shade, and water flows under them, and flowers bloom everywhere. In the Islamic architecture, Islamic gardens are based on such perception, upon intersecting canals in form of four quadrants [10].

\section{The impacts of Iranian beliefs on creation Persian Gardens}

Koran's message is that, at the judgment day, dead will wake up, and stand in bodily form. Deeds will be weighed and souls will be judged. After this judgment, the one will be rewarded or punished. The ones whose book of deeds given in their right hands will have the privilege to enter paradise. Those who obey the rules of Islam will gain the garden.

"And those who believe and do righteous deeds, we shall surely lodge them in lofty chambers of Paradise, underneath which rivers flow, therein dwelling forever; and excellent is the wage of labor, such men as are patient and put their trust in their Lord."

Islamic art and architecture prepare the soul for the promised world of Koran to the faithful. Mosques are the places where an expression of paradise symbolism becomes palpable through the use of light, colors and forms. According to Jale Erzen "As a sacred space, the interior of the mosque is made to remind one of a paradise of a garden of fragrant flowers and crystal ponds, a light ambiance".

Iranian gardens are usually designed in the shape of a square. The figure of the garden can either be a perfect square or a rectangle. According to square geometry, a quarter is considered as a circle and circles represent the depth of the universe. From ancient history, we know that the square Iranian gardens were inspired by the quartering circles as the basis of their designs in holy and sacred places.

The existence and preservation of the Persian garden is a reflection of the Iranian actual and religion. The garden also allows researchers to understand the religion, the culture, communities, and people. Furthermore, the garden is also a useful source to see how the Iranian gardening methods had an influence on the world [11].

\section{Pasargad Garden}

The archetype model of the Persian garden tradition is "Bagh". The terms "Bagh" and "Paradise" stand as a symbol of peaceful and joyful life with full of spiritual blessings. The term "the garden of paradise" has a deep sentimental and religious impact on the architecture and literature. The eldest Persian gardens date back to the Achaemenid Period and were found in Pasargadae (Figure 1). The originations of the main plan (four-part gardens) in Pasargadae were copied widely and with more complexity in all sub- sequent Persian and after that in Islamic gardens. The image of the paradise idea in Pasargadae's fourpart gardens is clearly evident (Figure 1) [12].

\section{Conclusion}

Behesht meaning 'paradise' in Iranian language This paradise can be seen as human home; outside which world is tumbling, and struggling, 
Citation: Nafisi N, Abbas MY, Nafisi S (2016) The Impact of Paradise in Persian Garden Design. J Steel Struct Constr 2: 113. doi:10.4172/24720437.1000113

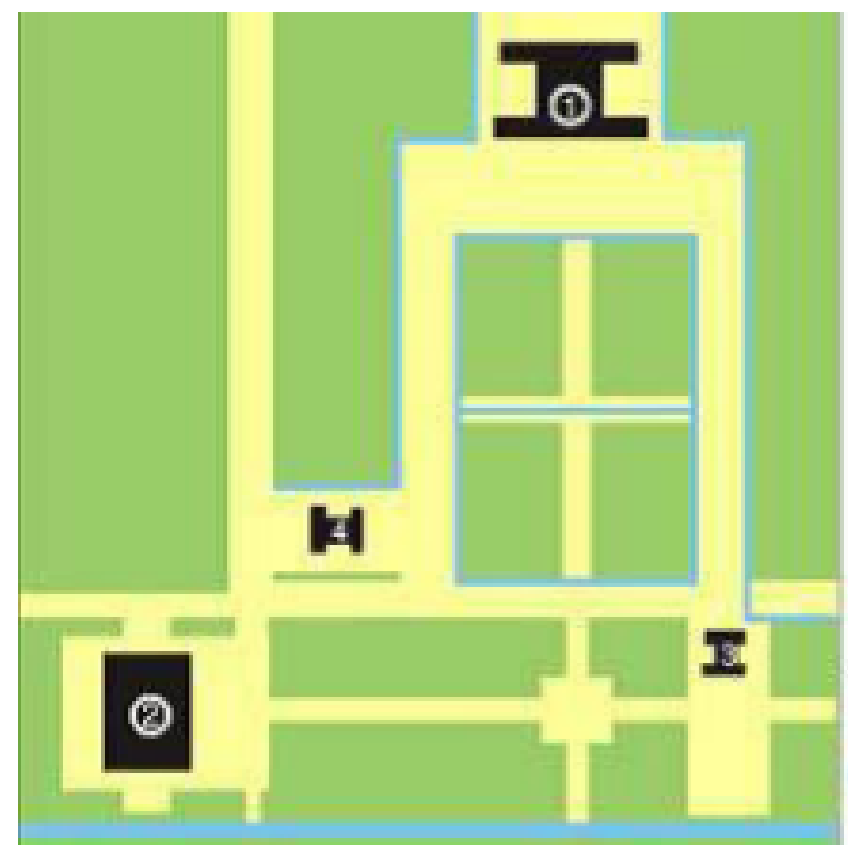

Figure 1: Pasargadae garden [12].

but inside is safe and sound. The garden is a portrayal of heaven with birds singing, and flowers blooming.

The influence of religion and belief was confirmed due to the common agreement that although Iran society is religious, Iranian architecture workers share certain common and religion values [13,14]. This research investigated the relationship between creation of Persian garden and religion. The findings confirmed that religion did impact on the creation of the garden.

\section{References}

1. Minorsk V (1938) Geographical Factors in Persian Art. University of London 9: $621-652$.

2. Delumeau J (1995) History of paradise: The Garden of Eden in myth and tradition. University of Illinois Press pp: 276.

3. Gharipour M, Caffey S (2012) Islamic and Renaissance Gardens: A Case for Mutual Influence? $2^{\text {nd }}$ International Meeting, Brussels, Belgium.

4. Mansouri SA (2004) Analyiss of Persian garden aesthetic, pp: 58-63.

5. Pirnia MK (1994) Essay of Persian gardens (baghhaye irani). Quarterly journal of architecture and urbanism Abadi, p. 4.

6. Pirnia MK (2009) Acquaintance with Islamic Persian Architecture. Memarian GHH (14th edn), publishing center of Soroosh Danesh, Tehran, p. 314.

7. Pope A (2004) Iranian Architecture. Farhangan, Trans. Sadri. Gh.

8. Zaitchik BF, Evas JP, Smith RB (2007) Regional Impact of an Elevated Heat Source: The Zagros Plateau of Iran. Journal of Climate 20: 4133-4146.

9. Ruggles DF (2008) Islamic Gardens and Landscapes. University of Pennsylvania Press, p. 296.

10. Clark E (2004) The Art of the Islamic Garden. Crowood Press, p. 208.

11. Nafisi N, Abbas MY, Nafisi S (2015) The Role of Belief and Religion in Creation of Persian Garden. Journal of Architectural Engineering Technology 4: $1-5$.

12. Ansari M, Taghvaee AA, Nejadi HM (2008) Cultural Beliefs Regarding Persian Gardens with the Emphasis on Water and Trees. African and Asian Studies 7: 101-124.

13. Kive SM (2012) The Other Space Of Persian Garden. An Interdisciplinary Arts and Sciences Journal 2: 85-96.

14. Pourmand H, Keshtkar A (2011) Analysis of the construction of the Persian Garden. Journal architecture and urban pp: 51-62. 